\title{
Profitability analysis of paddy production: A case of agricultural zone 1, Niger State Nigeria
}

\author{
Madu Ali Bwala and Aniobi U. John
}

Department of Agricultural Economics and Extension Services, Ibrahim Badamasi Babangida University Lapai

\section{ARTICLE INFO}

Article history:

Received: 16 January 2018

Accepted: 09 April 2018

\section{Keywords:}

Paddy rice, profitability, gross margin, profitability ratio, variable cost

\section{Correspondence:}

Madu Ali Bwala

(madubwala@gmail.com)

\begin{abstract}
This study estimated the profitability of rice production among small scale farmers in Bida agricultural zone of Niger state. The study utilized a multi-stage random sampling technique to select a total of one hundred and five (105) rice farmers in the area. The data was collected through a well-structured questionnaire from four communities in the study area. Descriptive statistics and farm budgeting tools were used for the analyses. The descriptive analysis showed that the farmers are highly productive between the age range of 37-48 years. Furthermore, results also revealed land area cultivated by the farmers to be generally below two hectares. The finding further revealed the variable cost per hectare for rice production to be $\$ 126,100$ per production cycle, while total revenue of $\$ 227,500$ was realized by the respondents. The results also revealed cost of labour to account for the largest portion $(54.0 \%)$ of the total variable cost. This is followed by the cost of seed, fertilizer, transportation, herbicide, pesticide and bagging. The farm budgeting analysis revealed the costs and returns of rice production to be profitable with a gross margin of $\$ 101,400$ and net farm profit of $\$ 98,546.4$. The gross profit ratio was calculated to be 0.45 which implies that farmers are selling their rice produce at a relatively high profit percentage. Based on the results obtained from the study, it was concluded that rice production in Bida Agricultural Zone of Niger State is profitable. Hence, the cultivation of rice is an important enterprise that should be encourage, considering the fact that it is a major staple. It is therefore recommended that timely availability of farm inputs such as improved seed variety and agrochemicals will further boos trice production in the area. Furthermore, provision of credit facilities to small scale farmers is a viable policy to be pursued.
\end{abstract}

\section{Introduction}

Rice production in Nigeria in recent times has received a boost that has for long been lacking. The impetus will enhance farmer's interest in crop production and hence improve their income potential. However, rice production in Nigeria is characterized by small scale farmers scattered across the country (Oyeyinka and Bolarinwa, 2009).Farmers carry out their operation using rudimentary farm tools, furthermore, lack of capital and poor yield per hectare is a challenge they have to contend with (Kolawale and Ojo, 2007). Being a staple consume by many households (Erebor, 1998), the rice crop may become a scarce commodity due to the fact that production is relatively low considering the large population of the country. The current production capacity of producers is quiet inadequate to meet the consumption demand of the nation (Bamidele et al.,2010). The inadequacy of rice harvest to meet consumption demand, provides an income enhancing opportunity for farmers as well as unemployed youths: Hence, the need for the promotion for the cultivation of the crop. Further more, agriculture being the primary source of employment to a majority of the population in Nigeria, places the rice crop as viable option for a livelihood strategy. It is therefore, important to ask the question "how profitable is the production of rice in the study area?".
Small scale farmers are the major players in rice production in Nigeria (Mgbenka et al., 2015). This is because the nation's agriculture has always been dominated by this group of farmers who cultivate less than 3 hectares but represent a substantial proportion of the total population and produce about $90-95 \%$ of the total agricultural output in the country (Oyeyinka and Bolarinwa, 2009, Yuguda, 2003). Rice is the fourth major cereal crop cultivated in Nigeria in terms of output and cultivated land area (Babafada, 2003, Ohaka et al., 2013). The production of rice in commercial quantity will contribute to the development of the Nigerian economy by saving the much needed foreign exchange used for the importation of rice from Asia and the rest of the world. To encourage the Nigerian farmers to produce rice in the required quantity, and also to stimulate large scale private investment in rice production; the profit making potential of rice production must be determined and ascertained.

The rice crop is important to the internal and subregional trade in Nigeria and Africa respectively. This is because the volume of rice traded at the local market is quite large (World Grain, 2016). The array of available rice varieties affords farmers the possibility to switch over to the crop every few years (Osiname, 2002). According to FAO (2010), the Nigerian rice sub-sector witnessed a remarkable increase in output from 2.5 
million metric tonnes in 1990 to about 4.2 million metric tonnes in 2008 which led to an increase in output of rice over the years as a result of increase in hectarage cultivated. However, in recent years, there has been a marked decline in the performance of Nigerian agricultural sector, the contribution of agriculture to Gross Domestic Product (GDP) which stood at an average of 56 percent in 1960-1964, declined to 47 percent in 1965-1969, further declined to 35 percent in 2002-2004 and there is recent increase to about 40 percent in 2009 (FAO, 2010). This falling yield of rice led to supply deficit situation in the country and in response to the situation, successive Nigerian governments have intervened in the rice sub-sector by increasing tariff on rice importation so that local production could be encouraged and hence expand the market for the local rice (Bamidele et al., 2010). The Nigerian Government has invested huge amount of money towards the improvement of rice varieties over the years. This is evidenced by the establishment of a research institute in the study area. The institute is saddled with the responsibility of harnessing the potential of the rice crop; with the objective of achieving a comparative advantage status for the country. The initiative has led to the development of several varieties of rice. Such varieties include: Faro 54, 57,52 and CP. The investment by Government in developing the cultivation of rice in Nigeria will be in vain if farmers do not adopt the improved varieties. Furthermore, rice cultivation has become a goldmine in recent years with the possibility of cultivating the crop twice in a year (dry and wet season): Hence, some farmers engage in the dry season cultivation of the crop. Based on the recent development of dry season cultivation of rice, more farmers are leveraging on the dry season cultivation opportunity. The attraction to cultivate the crop even during the dry season cannot be isolated from the potential of the crop in the wet season. Hence, the potential of the crop during the wet season need to be promoted to attract more farmers to cultivate the crop. By so doing, it is believed that when farmers experience the lucrative capability of the wet season cultivation, they may engage in dry season production of rice. Furthermore, this study aims to bring to the fore the available opportunity in the study area with respect to the cultivation of rice. Against this backdrop, this study examined the costs and returns associated with rice production in Bida agricultural zone, Niger State.

\section{Materials and Methods}

\section{Data and Sampling Procedure}

The research utilized primary data. The data was collected using interview method through a wellstructured questionnaire. A mixed sampling method was adopted for this study, where purposive and multistage random sampling techniques were utilized to draw the study areas and respondents. The first stage involved the purposive selection of three out of the eight Local
Governments in Bida agricultural zone. This is because rice is predominantly produced in relatively large quantities in these areas (i,e. Lavun, Mokwa and Katcha), hence the choice of the area. The second stage utilized random sampling technique to identify rice producing communities. The communities are Badeggi, Chanchaga, Manbe and Kedetifin. The third stage was the random selection of thirty five (35) respondents from each community giving a total of one hundred and five (105) rice farmers. The sample was taken from a population of about one thousand two hundred (1200) rice farmers.

\section{Analytical Technique}

The data were analyzed using descriptive statistics and farm budget analysis. The descriptive statistics were used to describe the socio-economic characteristics of rice producing farmers in the study area. Furthermore, the farm budget analyses which include revenue, cost, gross margin and net farm profit were utilized for the cost and returns estimation of rice production in the area. The Gross Margin which is the difference between the Total Revenue (TR) and the Total Variable Cost (TVC) was utilized to estimate the profitability of rice production in the area. This is because the Gross Margin is a useful planning tool in situations where fixed capital is a negligible part of an enterprise. This is the case of small scale rice producers in the study area (Omotosho et al, 2010, Abdullahi, 2012). The gross margin model is expressed as:

$$
\begin{aligned}
& \mathrm{GM}=\mathrm{TR}-\mathrm{TVC} \text {................. (1) } \\
& \text { - Where: } \\
& \text { - } \mathrm{GM}=\text { Gross Margin }(\$ / \mathrm{Ha}) \\
& \text { - } \quad \mathrm{TR}=\text { Total Revenue }(\$ / \mathrm{Ha}) \\
& \text { - } \quad \mathrm{TVC}=\text { Total Variable Cost }(\$ / \mathrm{Ha})
\end{aligned}
$$

Profitability ratio was further used to examine the costs and return of the farmers. This is because gross margin though necessary but is not a sufficient tool to determine the profitability level of an enterprise. Furthermore, profitability ratios are a class of financial metrics that are used to assess an enterprise ability to generate earnings compared to its expenses and other relevant costs incurred during a specific period of time (James, 2009).

Hence the model is presented thus:

$$
\text { Gross Profit Ratio }=\frac{\text { Gross Margin }}{\text { Total Revenue }} \times 100 \ldots \ldots \ldots .
$$

\section{Results and Discussion}

\section{Descriptive Analysis of Socio-economics Characteristics}

The socio-economic characteristics of rice farmers directly or indirectly affect their farming operations. The result revealed that a high percentage of the farmers $(52.4 \%)$ are between the age group of $37-48$ years (Table 1, Appendix I). This indicates that young adults 
are actively involved in farming activities. Considering the age range of a majority of the farmers, their productivity is at its peak and hence is of great value to rice production. Yakubu, (2002) concurred with this finding based on his assertion that farmers who are between the ages of 30-49 years are more willing and able to take risk with the expectation of a larger profit than the older farmers.

Household size is an important source of family labour, the study revealed that majority of the respondents had family size ranging between 6-10 persons in the family (41\%). This implies that the farmers in the study area might have advantage as regards unpaid family labour availability since majority of the household had members that can participate in farm work. The availability of this unpaid labour reduces the cost of farm labour. However, according to Okoruwa and Ogundele (2006) large family size does not necessarily translate to high usage of family labour. This is because some of the able bodied family members may prefer other jobs/vocation rather than farming (Table 1).

Furthermore, the findings revealed that majority of the rice farmers $(43 \%)$ had farming experience less than 15 years (Table 1). This implies that farmers with more farming experience are likely to be more versatile regarding the proper timing of land preparation, planting, application of agrochemicals, harvesting, threshing and preservation good seeds for the next farming season. This finding is corroborated by Abu et al. (2011) where they reported that farming experience is a determinant of the ability of the farmer to make good farm management decisions effectively. This is not limited to only following the agronomic practices, but also with the right combination of inputs for a profitable farm venture.

Education is known to facilitate farmers' understanding and use of improved crop production practices. Table 1 shows that $35.2 \%$ of the farmers had Quranic form of education followed by secondary education. The result reveals that all of the respondents have had a form of education, with about $65 \%$ of them having western education. It is therefore, expected that the rice farmers are knowledgeable and apt to learn. Hence, the introduction of new technologies in the area should also be expected to be with minimal or no resistance. This is because, Muhammad et al. (2009), asserted in their study that level of education is expected to influence farmers' adoption of agricultural innovations and also improve decision making on various aspects of farming.

The area of land cultivated by the farmers is important as well. The size of land cultivated determines to a large extent the crop population on the farm and consequently the quantity of harvest. Table 1 reveals that majority of the farmers $(47.5 \%)$ cultivated land sizes that were less than or equal to 2 hectares. Furthermore, about $41 \%$ of the farmers cultivate land size of 3-4 hectares while a smaller percentage of the farmers cultivated the rice crop on land areas that were greater than 5 hectares. This finding implies that the cultivated land areas were generally of small sizes (Lowder et al., 2016) and could be limiting factor to the level of output by the farmers in the study area. This finding is corroborated by the work of Okunlola and Adekunle, (2000) where it was reported that a majority of the Nigerian farmers operate at the small scale level.

Regarding contacts with extension services, the result show that majority of farmers $(52.4 \%)$ had no contact with extension agents throughout the year. A reasonable number of the farmers $(47.6 \%)$ had contact with extension agents ranging from 1-4 times per year, while $10.5 \%$ of the farmers had contact with extension agents ranging from 3-4 times a year. This finding implies that farmers in the study area had insufficient extension visits; this development could limit the farmer's awareness on new farm technology and distribution of farm inputs. According to Obwona (2000), extension service is very essential to the improvement of farm productivity and efficiency among farmers (Table 1).

Table 1. Socio-economic Characteristics of Respondents

\begin{tabular}{|c|c|c|}
\hline & Frequency & Percentage \\
\hline \multicolumn{3}{|l|}{ Age } \\
\hline$\leq 25$ & 3 & 2.9 \\
\hline $26-36$ & 29 & 27.6 \\
\hline $37-48$ & 55 & 52.4 \\
\hline $49 \leq$ & 18 & 17.1 \\
\hline Total & 105 & 100.0 \\
\hline \multicolumn{3}{|l|}{ Household Size } \\
\hline$\leq 5$ & 21 & 20.0 \\
\hline$\overline{6}-10$ & 43 & 41.0 \\
\hline $11-15$ & 31 & 29.5 \\
\hline $16 \leq$ & 10 & 9.5 \\
\hline Total & 105 & 100.0 \\
\hline \multicolumn{3}{|l|}{ Farming Experience } \\
\hline$\leq 15$ & 43 & 41.0 \\
\hline $16-23$ & 26 & 24.8 \\
\hline $24-31$ & 28 & 26.7 \\
\hline $32-39$ & 5 & 4.8 \\
\hline $40 \leq$ & 3 & 1.0 \\
\hline Total & 105 & 100 \\
\hline \multicolumn{3}{|c|}{ Educational Attainment } \\
\hline Primary & 23 & 21.9 \\
\hline Secondary & 30 & 28.6 \\
\hline Tertiary & 6 & 5.7 \\
\hline Adult & 9 & 8.6 \\
\hline Quranic & 37 & 35.2 \\
\hline Total & 105 & 100 \\
\hline \multicolumn{3}{|l|}{ Land Size } \\
\hline Less than 2 & 50 & 47.5 \\
\hline $3-4$ & 43 & 41.0 \\
\hline $5-6$ & 6 & 5.7 \\
\hline More than 7 & 6 & 5.7 \\
\hline Total & 105 & 100 \\
\hline \multicolumn{3}{|c|}{ Contact with Extension Agent } \\
\hline Number of contact & 55 & 51.4 \\
\hline $1-2$ & 39 & 37.1 \\
\hline $3-4$ & 11 & 10.5 \\
\hline Total & 105 & 100 \\
\hline
\end{tabular}

Source: Field Survey, 2016. 
The variety of a crop cultivated determines to a large extent the returns the farmer gets from the enterprise. Results revealed that $59.0 \%$ of the farmers plant improved variety of rice, while $32.4 \%$ planted the local variety (Figure 1). The improve variety planted by the farmers include Faro 52, Faro 51 and CP. Farmers plant these varieties in the wet season, furthermore, the maturity period spans from 100 to 115 days.

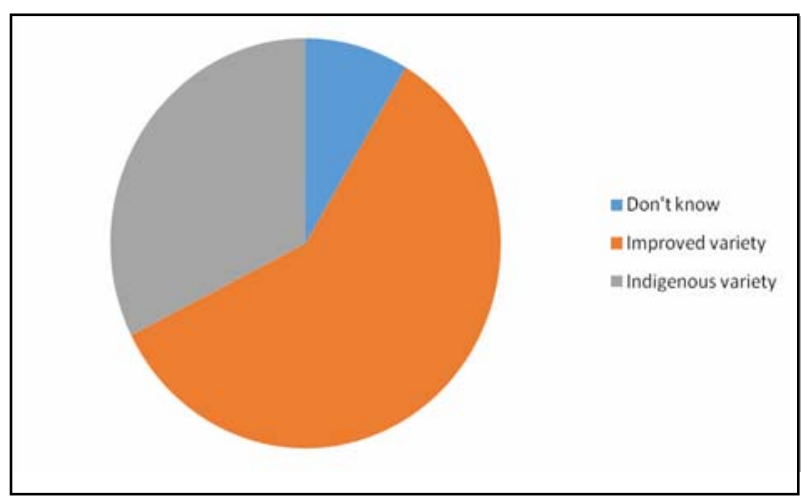

Figure I. Rice variety cultivated by farmers

From the results it is clear that some of the farmers (32.4\%) still plant local varieties. The implication of this finding is that farmers who plant local variety may not have as much harvest as those who plant the improved variety.

Profitability of Rice Production in Agricultural Zone I This section examines the profitability of rice production in agricultural zone I. To determine the profit level, attempts were made to estimate the cost and return from rice farming. The gross margin and gross profit ratio associated with rice production were estimated, due to the fact that the fixed cost for small scale rice production is negligible. Thus for this study, only variable costs were considered and hence calculated. These costs include cost of seeds, fertilizer, pesticides, bags, labour and fixed costs were used. Furthermore, returns were calculated based on average price that farmers received per kg of rice. The average cost of producing one hectare of rice was calculated for all the categories of farms as presented in Table 2. The result reveals that cost of labour accounted for the largest proportion $(54.0 \%)$ of the total variable cost. This is followed by the cost of seed, fertilizer, transportation, herbicide, pesticide and bagging. This clearly indicate that large amount of resources is invested on labour requirements. This finding is corroborated with the assertions of Ereinstein, et al., (2004) \& Duvvuru and Motkuri, (2013) that "Rice production is labour intensive and relies on a significant usage of paid labour" in most cases.

The finding further revealed the variable cost per hectare for rice production was found to be $\$ 360.29$ per production cycle, while total revenue of $\$ 650$ was realized by the respondents. Meanwhile, the gross margin and gross profit were estimated to be $\$ 289.71$ and $\$ 281.56$ respectively. The gross profit margin was calculated to be 0.45 which is equivalent to $45 \%$. A high gross profit ratio is an indication that the farmers are selling their produce at high profit level. Hence, the farmer are expected to have sufficient funds to pay for operating expenses such as wages, utilities and rent while having high turnover in the study area. This finding is in consonance with the finding of Ekpe and Alimba (2013), where they reported that rice production in Ebonyi State has positive gross margin because total revenue is far more higher than total variable cost. The profitability of rice enterprise and of course farmers' income is expected to increase significantly when more land is allocated to the production of rice (Table 2).

Table 2. Profitability of Rice Production

\begin{tabular}{|c|c|c|c|c|c|c|}
\hline Item (Annually) & Qty & Unit Price (\$) & Useful Life (year) & Depreciation Cost (\$) & Value/Ha (\$) & $\%$ of Total Cost \\
\hline Total Revenue/Ha & 35 & 18.57 & & & 650.00 & \\
\hline \multicolumn{7}{|l|}{ Variable Cost } \\
\hline \multicolumn{7}{|l|}{ Labour } \\
\hline Family (Md) & 47 & 2.29 & - & - & 107.43 & 29.2 \\
\hline Hired (Md) & 40 & 2.29 & - & - & 91.43 & 24.8 \\
\hline Seed $(\mathrm{Kg})$ & 50 & 1.00 & - & - & 50.00 & 13.6 \\
\hline Fertilizer $(100 \mathrm{~kg})$ & 4 & 17.14 & - & - & 68.57 & 18.6 \\
\hline Pesticide (Liter) & 3 & 3.14 & - & - & 9.43 & 2.6 \\
\hline Bag (120kg) & 35 & 0.34 & - & - & 12.00 & 3.2 \\
\hline Transportation & - & & - & - & 21.43 & 5.8 \\
\hline TVC/Ha & - & & - & & 360.29 & \\
\hline Fixed Cost & & & - & & 0.00 & \\
\hline Hoe & 4 & 2.57 & 2 & 1.71 & 1.71 & 0.5 \\
\hline Cutlass & 5 & 3.43 & 2 & 2.86 & 2.86 & 0.8 \\
\hline Basket & 6 & 1.14 & 2 & 1.14 & 1.14 & 0.3 \\
\hline Knife & 3 & 0.71 & 4 & 0.18 & 0.18 & 0.1 \\
\hline Sickle & 4 & 2.86 & 3 & 1.27 & 1.27 & 0.4 \\
\hline Sprayer & 1 & 14.86 & 5 & 0.99 & 0.99 & 0.3 \\
\hline Total Fixed Cost & - & - & & 8.15 & 8.15 & - \\
\hline Total Cost & - & - & & & 368.44 & - \\
\hline Gross Margin & - & - & & & 289.71 & - \\
\hline Net Farm Profit & - & - & - & & 281.56 & - \\
\hline Gross Profit Ratio & - & - & - & - & 0.45 & - \\
\hline
\end{tabular}

Source: Field Survey, 2016. 


\section{Constraints}

Generally, there are several factors militating against the cultivation of crops, however, every crop enterprise has peculiar conditions that adversely affects its production. This could be either physiological, environmental or the marketing of the crop. This section examined the constraint rice farmers in the study area experienced. From the results, high cost of inputs was found to be a challenge to more than one third (36.19\%) of the farmers (Table 3). A further $24.76 \%$ of the farmers reported lack of access to loan as a challenge. Flooding was also reported as a factor affecting the production of rice in the area. This is because there are seasons that the rains flood the farmlands when the crop is close to maturity, leading to colossal damage of the grains.

\section{Table 3. Constraints Militating Against Rice} Production in the Study Area

\begin{tabular}{lcc}
\hline Problems Encountered & Frequency & Percent \\
\hline Cost of farm inputs & 38 & 36.19 \\
Access to loan & 26 & 24.76 \\
Flooding & 18 & 17.14 \\
Price instability & 13 & 12.38 \\
Others & 10 & 9.52 \\
Total & 105 & 100 \\
\hline
\end{tabular}

\section{Conclusion and Recommendation}

Rice production in Bida Agricultural Zone of Niger State is profitable. Hence, it is an important agricultural enterprise that should be encourage among farmers, considering the fact that it is a major staple. The promotion of rice production among farmers will increase availability and affordability of the grain, enhance income generation of farmers; and improve food security at the household and national level. It was therefore recommended that farmers should have better access to credit facilities. Also farmers should be enlightened by extension agents on the benefits of using improved variety of rice. Further more, weather forecast accompanied by extension with regards to rainfall intensity will help farmers plan against flooding.

\section{Reference}

Abdullahi, A. 2012. Comparative Economic Analysis of Rice Production by Adopter and non-Adopter of improved varieties of rice among farmers in Paikoro LGA of Niger state. Nigeria J. Basic and Appl. Sci.. 20(2): 146-151.

Abu, G.A., Abah, D. and Okpachu, S.A. 2011. Analysis of Cost and Return for Sesame Production in Nasarawa State: Implication for Sustainable Development in Nigeria. $J$. Sustain. Dev. Africa 13(3): 238-249.

Babafada, M. 2003. Integrated Rice Production and Export in Nigeria, Paper presented at a seminar on sustainable rice production in Nigeria, Organized by Central Bank of Nigeria, held at Hamadala hotel, Kaduna from January 14 th to $15^{\text {th }}: 1-4$.

Bamidele, F.S., Abayomi,O.O. and Adebiyi E.O. 2010. Economic Analysis of Rice Consumption Pattern in Nigeria, J Agril. Technol. 12:1-3.

Duvvuru, N. R. and Motkuri, V. 2013. Declining Labour Use in Agriculture: A Case of Rice Cultivation in Andhra Pradesh. Paper No. 49204 Available at www.mpra.ub.unimuenchen.de.

Ekpe, I.I. and Alimba, J.O. 2013. Economics of Rice Production in Ebonyi State South Nigeria, International Journal of Food,
Agriculture and Veterinary Sciences ISSN: 2277-209X (Online) An Online International Journal Available at http://www.cibtech. org/jfav.htm 2013 Vol. 3 (2): 77-81.

Erebor, O. 1998. Comprehensive Agricultural Science for Senior Secondary Schools. Lagos: Johnson Publishers Ltd.

Ereinstein, O., Lançon, F., Osiname, O. and Kebbeh, M., 2004. Operationalising the Strategic Framework for Rice Sector Revitalisation in Nigeria. Project Report -The Nigerian Rice Economy in a Competitive World: Constraints, Opportunities and Strategic Choices. Abidjan: WARDA The Africa Rice Centre.

Food and Agriculture Organization 2010. FAOSTAT Online Datase, Available at http//faostatfao.org and http://en.wikipedia. org/wiki/rice Food and Agriculture Organisation of United Nations. Rome.

Kolawale, O. Ojo, S.O.2007.Economic efficiency of small scale food crop production in Nigeria. J. Soci. Sci. 14(2): 123-125.

James, C. 2009. "Financial Statement Analysis in Accounting: Liquidity Ratio Analysis, Balance Sheet Assets and Liabilities". Jo. Finan. Stat.

Lowder, S. K., Jakob, S., Raney, T. 2016. The Number, Size, and Distribution of Farms, Smallholder Farms, and Family Farms Worldwide. World Development Volume 87:16-29.

Mgbenka, R.N.,Mbah, E.N. and Ezeano, C.I. 2015. Review of Small holder Farming in Nigeria: Need for Transformation. Agricultural Engineering Research Journal 5(2): 19-26.

Muhammad, L., Omotesho, A., and Falola, A. 2009. Technical efficiency of youth participation in agriculture programme in Ondo State, Nigeria. Nigeria J. Agric. Food and Environ. 5(1): 20-26.

Obwona, M. 2000. Determinant of technical efficiency among small and medium scale farmers in Uganda: A case of tobacco growers. Final Report at the AERC Biannual Research Workshop, Nairobi, Kenya.

Ohaka, C.C., Adiaha, M.M. and Amanze, P.C. 2013. Economic analysis of small holder rice production in Ihite-Uboma L.G.A of Imo State. Nigeria J. Agric. Food and Environ.. 9(2): 37-41.

Okoruwa, V.O. and Ogundele, O.O. 2006. Technical Efficiency Differentials in Rice Production Technologist in Nigeria. African Economic Research Consortium, Research paper No. 154.

Okunlola, J.O and Adekunle, O. 2000. Indigenous Knowledge Approach for Rice Pests and Diseases Control for sustainable Environmental Management by Rice Farmers in Niger State, Nigeria. Journal of Environmental Extension 1 (1): 28-35.

Osiname, O.A 2002. Review of Current Status, Policy and Prospects of Rice production in Nigeria. Paper Presentation at the Rice Stakeholders Workshop. Nigerian Institute of Social and Economic Research (NISER). 19th-20th November.

Omotosho, A.O., Muhammad, L. A. and Yusuf, Y.K. 2010. Economics of small scale rice production in Patigi and Edu Local Government Areas of Kwara State, Nigeria. Afr. J. Agric. Res. 5(4). www.nigerstate.gov.ng/about.

Oyeyinka, R.A, and Bolarinwa, K.K. 2009. Using Nigerian Agricultural Cooperate and Rural Development Bank small holder direct loan scheme to increase agricultural production in rural, Oyo state, Nigeria. International $J$ Agril. Econ. and Rural Dvelop.-2(1)

World Grain,2016. Rice is king in west and central Africa. Available at http://www.world-grain.com

Yakubu, S. 2002. Economic Analysis of Groundnut Production in Azare Municipal, Katagum L.G.A of Bauchi State. An unpublished B. Tech. Project of Agricultural Economics and Extension Programme ATBU Bauchi: 62

Yuguda, U. 2003. Towards a Sustainable Rice Production in Nigeria. Paper Presented at a Seminar on Sustainable Rice Production in Nigeria Organized by Central Bank of Nigeria at Hamadala Hotel, Kaduna, Jan. 14-15 :16-22. 